\title{
Necrotising soft-tissue infection
}

\author{
Miguel F Carrascosa, ${ }^{1}$ Mariano Pérez Santamaría, ${ }^{2}$ José-Ramón Salcines Caviedes, ${ }^{1}$ \\ Pablo G Gutiérrez ${ }^{3}$
}

${ }^{1}$ Department of Internal Medicine, Hospital of Laredo, Laredo, Cantabria, Spain

${ }^{2}$ Service of Orthopedic and Traumatologic Surgery, Hospital of Laredo, Laredo, Cantabria, Spain

${ }^{3}$ Service of Radiology, Hospital of Laredo, Laredo, Cantabria, Spain

Correspondence to Dr Miguel F Carrascosa, miguel.carrascosa@scsalud.es

\section{DESCRIPTION}

A 55-year-old woman presented with a 3-day history of progressively worsening pain, swelling and 'unpleasant crackling feeling' on her left upper limb. These complaints had begun after she noticed a small reddish lesion on her left elbow. The patient had received a diagnosis of systemic lupus erythematosus 15 years before coming to us and was taking methylprednisolone and acenocoumarol, the last for previous deep vein thrombosis associated with protein $\mathrm{S}$ deficiency. There was history of neither acute or chronic trauma nor diabetes (in the patient or in her family). She was allergic to penicillin. On admission, blood pressure and temperature were normal but heart rate was 99 beats/min. Her left upper extremity showed erythema, an elbow wound (figure 1), and generalised tense oedema and crepitus, the last also being evident on the ipsilateral supraclavicular region. Plain radiographs of the left upper limb and chest identified abundant subcutaneous gas (figure 2 and 3 ), a very specific finding of necrotising soft-tissue infection (NSTI). The patient was immediately started on intravenous clindamycin and vancomycin and then urgent, extensive surgical

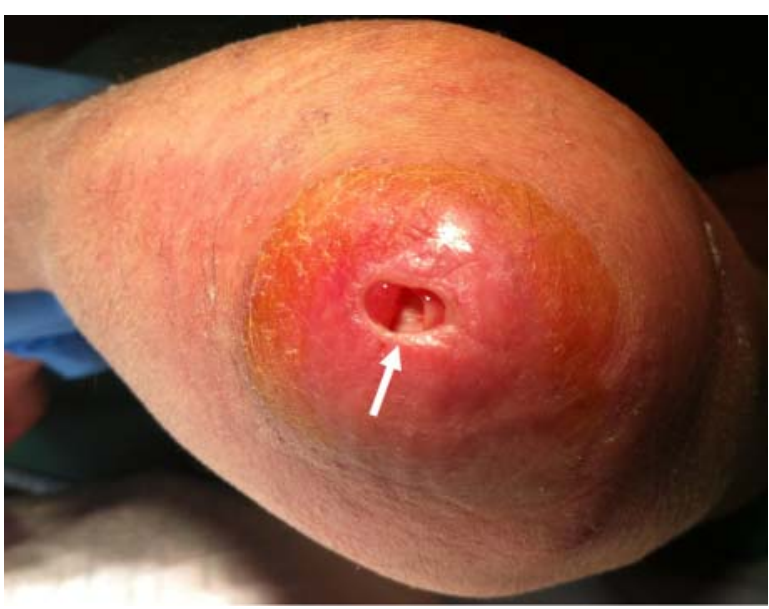

Figure 1 Left elbow appearance on admission showing a non-exudative, ulcerative lesion (arrow) with surrounded oedema and erythema (suspected portal of entry for the infection). The visible portion of the left upper extremity is swollen and erythematous.

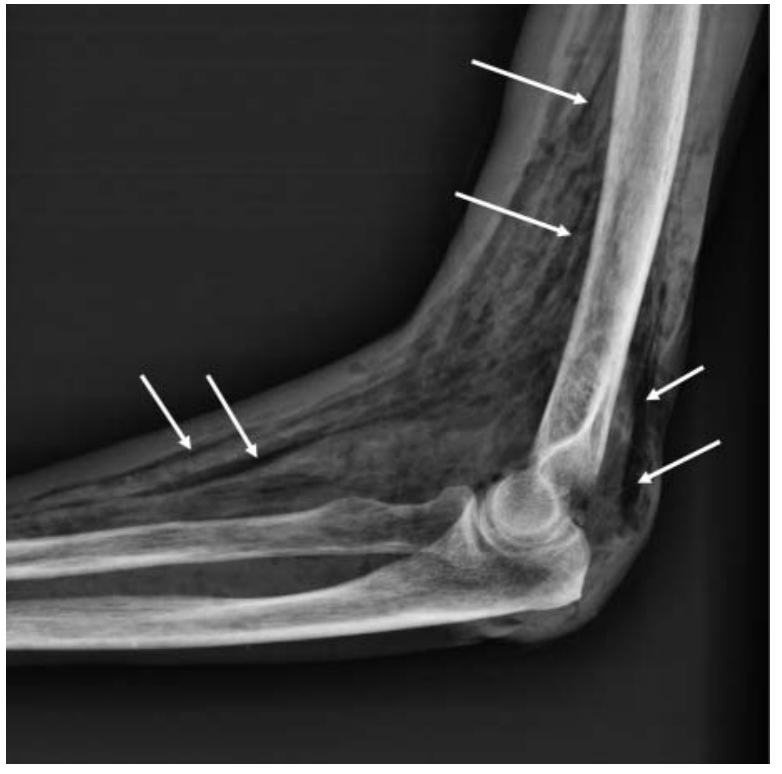

Figure 2 Plain radiography of the left upper extremity revealing the presence of subcutaneous widespread gas (arrows).

'Dissection' of muscular and other tissular structures by the gas can be appreciated.

debridement of the necrotic tissue was performed. She afterwards received hyperbaric oxygen as an adjunct to operative procedure and antibiotics. Culture of several samples obtained from the necrotic tissue grew no microorganisms. The postoperative course was uneventful and she was discharged on hospital day 11.

NSTI is infrequent but still remains a highly lethal disorder. ${ }^{1}$ Some patients seem to be more prone to develop this condition, as those with diabetes mellitus, immunosuppression, obesity and intravenous drug use. ${ }^{12}$ Other reported risk factors are age greater than 50 years, peripheral vascular disease and chronic alcoholism. ${ }^{2}{ }^{3}$ Although NSTIs are more commonly polymicrobial, ${ }^{1-3}$ the aetiology may remain unknown in some patients. ${ }^{1}$ Early and aggressive surgical debridement combined with empiric broadspectrum antimicrobial therapy and physiological support are of paramount importance to increase the survival likelihood. $^{1-3}$

Competing interests None

Patient consent Obtained. 


\section{BMJ Case Reports}

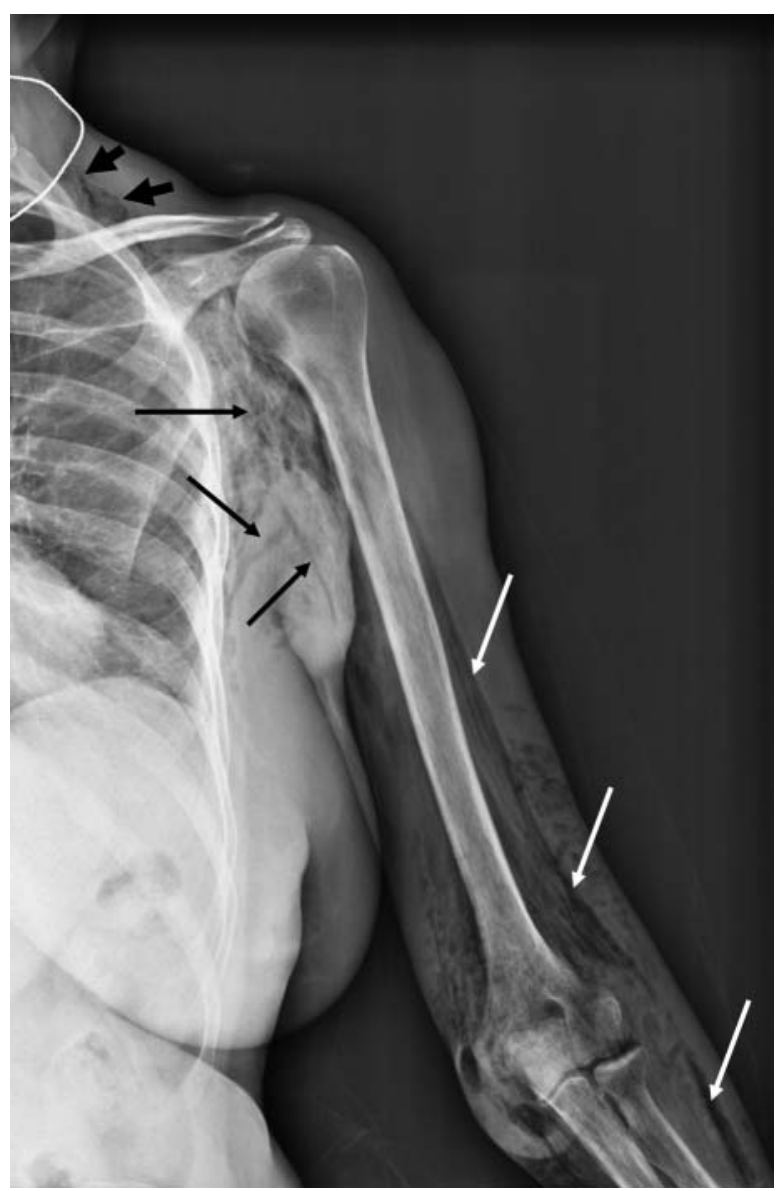

\section{REFERENCES}

1. Anaya DA, Dellinger EP. Necrotizing soft-tissue infection: diagnosis and management. Clin Infect Dis 2007;44:705-10.

2. Ustin JS, Malangoni MA. Necrotizing soft-tissue infections. Crit Care Med 2011;39:2156-62.

3. Headley AJ. Necrotizing soft tissue infections: a primary care review. Am Fam Physician 2003;68:323-8.

Figure 3 Plain radiograph showing the existence of

subcutaneous gas in the left upper limb (white arrows) and the ipsilateral both hemithorax (thin black arrows) and supraclavicular area (thick black arrows).

This pdf has been created automatically from the final edited text and images.

Copyright 2012 BMJ Publishing Group. All rights reserved. For permission to reuse any of this content visit http://group.bmj.com/group/rights-licensing/permissions.

BMJ Case Report Fellows may re-use this article for personal use and teaching without any further permission.

Please cite this article as follows (you will need to access the article online to obtain the date of publication).

Carrascosa MF, Santamaría MP, Caviedes J-RS, Gutiérrez P G. Necrotising soft-tissue infection. BMJ Case Reports 2012; 10.1136/bcr-2012-007025, Published XXX

Become a Fellow of BMJ Case Reports today and you can:

- Submit as many cases as you like

- Enjoy fast sympathetic peer review and rapid publication of accepted articles

- Access all the published articles

- Re-use any of the published material for personal use and teaching without further permission

For information on Institutional Fellowships contact consortiasales@bmjgroup.com

Visit casereports.bmj.com for more articles like this and to become a Fellow 